\title{
Doomed Mythic Artist: Sam Shepard's Angel City
}

\author{
Shima Shahbazi \\ Sheikhbahaee University, Isfahan, Iran \\ Hossein Pirnajmuddin \\ English department, University of Isfahan, Iran
}

\begin{abstract}
Sam Shepard is one of the most popular postmodern playwrights. His plays have a mythic quality. The myths he creates are considered as postmodern; they are parodic by nature and emblematic of American pop culture. "Myth of the artist" is highlighted in many of his plays concerned with the notion of art. Angel City hinges on the corruption of the artistic imagination and the doom of the American dream; on the whole, it is a postmodern sublime-- a parody of the modernist apocalyptic vision or dystopia. This play, like Shepard's other plays, is considered historiographic in that it deals with the past representations and attempts at reviewing and questioning the past. This article addresses the historiographic quality of Shepard's Angel City, with emphasis on Linda Hutcheon's poetics of postmodern historiography and Roland Barth's conception of modern myths in relation to patterns of culture. The parodic aspect of the play, it is argued, poses a critical stance vis-à-vis the past representations of the myths and the elitist approach of modernist art. In this study, the aim is to show how Shepard has questioned notions such as the myth of capitalism, myth of origin, myth of the savior, myth of the American dream, and myth of mission in the context of art and how the old myths of hero turn into myths of anti-hero in postmodern drama.
\end{abstract}

Index Terms - Sam Shepard, Angel City, historiography, myth of the Artist, parody, the Postmodern

\section{INTRODUCTION}

Like many other plays of Sam Shepard - the postmodern American playwright-Angel city (1976) deals with the notion of art. Angel City, blending high art and the popular culture, is a postmodern LA noir, a pastiche and parody of the noir genre. The play is an interplay of clashing elements from various film genres, namely, film noir, schlock-horror, disaster movies, incorporating everything from channel surfing to Hopi Indian lore and Japanese martial arts (Bottoms, 1998). It also incorporates and plays ironically on the fictional patterns found in Nathaniel West's The Day of the Locust and other noir texts (Wilcox, 1993).

What all the noir texts and movies share is the dystopianization of Los Angeles which is a common theme in the works of Raymond Chandler, Dashiell Hammett, and Budd Schulberg and directors like Orson Welles (Wilcox, 1993). Angel City renders the same theme but with a different technique, that is, historiographic metafiction.

Historiography, generally speaking, is the study of the history and methodology of the discipline of history. La Capra has defined it as a "reconceptualization of culture in terms of collective discourses" (in Hutcheon, 1988, p. 15). Linda Hutcheon uses the term historiography in defining postmodern literature and culture. She maintains that history is a hallmark of postmodernism. According to her, postmodernism suggests a "re-evaluation of and a dialogue with the past" in the light of the present (p. 19). She declares that in postmodernism, the past can no more be denied than unproblematically returned to; it is always "placed critically and not nostalgically in relation with the present" (ibid.). Therefore, she views the past in postmodernism as a critical revisiting.

Unlike Baudrillard who believes in the nostalgic aspect of postmodernism, Hutcheon disproves this nostalgic aspect and does not approve of the theory that calls postmodern representations meaningless and centerless simulacra (Hutcheon, 1988). Instead, she focuses on "parody" which brings about this "reviewing" and "critical" characteristic of postmodernism. Parody, as she argues, calls our attention to the history of the images and icons or, better to say, the representations we meet in today's culture. The paradoxical nature of postmodernism is generated by "parody" for it "paradoxically incorporates and challenges that which it parodies" (ibid, p. 6). Parody seems to offer a perspective on the present and the past which "allows an artist to speak to a discourse from within it but without being totally recuperated by it" (ibid. p. 35).Therefore, parody brings about a critical distance which makes possible a roughly objective reading of the past. It offers a sense of "the presence of the past," a past that can be known from its documents (ibid. p. 125). Postmodern historiography, using "parody" as a technique, raises questions regarding the nature of identity and subjectivity, reference and representation and the ideological implications of writing about history (Hutcheon, 1988).

Parody contests the assumptions about artistic originality and uniqueness and the notions of ownership and property. With parody - as with any form of reproduction - the notion of the original as rare, single, and valuable (in aesthetic or 
commercial terms) is called into question. This does not mean that art has lost its meaning and purpose, but that it will inevitably have a new and different significance. In other words, parody works to "foreground the politics of representation" (Hutcheon, 1989, pp. 93-94), to "enshrine the past and to question it" (Hutcheon, 1988, p. 125).

It is worth mentioning that Hutcheon has mostly focused on historiographic metafiction because postmodernism in literature has been mostly defined for fiction; but her definitions and theories are also applicable to literature including drama. In historiographic literature, the historical and literary inscriptions merge and make up intertextuality (ibid, p. 143).

Postmodern drama or generally speaking postmodern art and literature are self-reflexive and simultaneously historically grounded and they bear a history of themselves within their textuality. As we will discuss, Sam Shepard's postmodernist plays (Angel City in focus) are self-reflexive since they are concerned with art, artists and the history of the formation of art.

In this study, myth - as a "mode of representation" chosen by history (Barthes, 1957, p. 108) —is considered a sort of historiography. Sam Shepard's myths can be classified as Barthesian "modern myths": Pop culture heroes (who turn out to be parodic anti-heroes) like musicians, actors and actresses, showbiz men, movie producers, rock and rock singers and etc. Shepard produces these mythic figures to review the history of American culture, including the myth of capitalism and myth of origin.

\section{DISCUSSION}

In Angel City, Rabbit Brown, an artist who has been living on the desert, is summoned by two movie producers named Lanx and Wheeler to come and serve as a script doctor on a failing movie project. The plan of Lanx and Wheeler is to exploit Rabbit's "magic" to save their movie. But ironically, Rabbit who is supposed to be a savior is himself mesmerized by the power of Hollywood and loses his sense of mission.

Angel City hinges on the corruption of the artistic imagination and the doom of the American dream; on the whole, it is a parody of the modernist apocalyptic vision. It is actually directly related to Shepard's experience when, as a young Off-Off Broadway playwright of 24, he was chosen by Michelangelo Antonioni to write the screenplay for his film about the new generation of American youth, Zabriskie Point (1970). However, he left the project for Antonioni wanted a political repartee and Shepard could not handle it (Murphy, 2002).

Although Shepard's play is critical of many issues, his radicalism, As Innes maintains, is not expressed in terms of any political ideology; rather his attack is on the psychology of the status quo, and his target (like that of more conventional playwrights, such as Arthur Miller or Edward Albee) is the American Dream, encapsulated in Hollywood (Innes, 1993).

The play is primarily concerned with "character making". In the very beginning Lanx states that in their job, what is missing is "a meaningful character" (p. 67) and they have called upon Rabbit to get help in this regard. They are trying to create something transcendental and unearthly. The characters of the play are unable to fulfill this mission for they are themselves fragmented pieces of a whole character. As Shepard explains in Note to the Actors:

The term "character" could be thought of in a different way when working on this play. Instead of a "whole character" with logical motives behind his behavior which the actor submerges himself into, he should consider instead a fractured whole with bits and pieces of character flying off the central theme. In other words, more in terms of collage construction or jazz improvisation. This is not the same thing as one character playing many different roles ... If there needs to be a "motivation" for some of the abrupt changes which occur in the play they can be taken as full-blown manifestations of a passing thought or fantasy. (in Shepard, 2006, pp. 61-62)

The characters of Angel City are stuck by the images and myths; in other words, as Wilcox argues (p. 63), their subjectivity is colonized by the images and myths of Hollywood. Hollywood is considered as one of the instances of postmodern sublime, "criminally figured and marked by urbanization, commodification, and technology" (Callens, 2002, p. 199). Sublime rooted in disharmony and disruption has become a vital figure in the postmodern theory (Malpas, 2005, p. 62). Lyotard (1992, p. 14) distinguishes between the modern and the postmodern sublime by arguing that in the former the unpresentable is "invoked only as absent content, while the form, thanks to its recognisable consistency,continues to offer the reader material for consolation or pleasure", while the latter "invokes the unpresentable in presentation itself' (ibid, p. 15).

Angel City has postmodern and surreal characteristics. As Shepard himself explains, characters are collage-like and this quality leads to a parodic intertextuality in the play. The passing thoughts and fantasies of the characters make the play monologic in some parts, revealing a "pure psychic automatism by which it is intended to express... the real process of thought, free from any control by the reason and of any aesthetic or moral preoccupation" (Breton, as cited in Haqiqi, 1383, p. 248). This also brings about a surrealist quality which makes the play easier to read than act out (emphasizing the pictorial aspect of popular culture).

The postmodern sublime incorporates images of doom and devastation. In Angel City "disaster" functions as the postmodern sublime; it is something that is supposed to represent what is unpresentable, that is, death. Believing that they can save themselves from "total annihilation" $(A C$, p. 71) only by injecting a major disaster in the movie, Wheeler and Lanx assign Rabbit to come up with "something which will in fact drive people right off the deep end . . . something which not only mirrors their own sense of doom but actually creates the possibility of it right there in front of 
them ... we must help them devour themselves or be devoured by them" (AC, p. 71). The descriptions in the beginning of the play are all dystopian images that are presented in the form of a screenplay:

LANX: "Outside, the smog strikes clean to the heart. Babies' eyes bleed from it. ...Grown men kneel over, Dogs go paralyzed...all along through the terrifying shopping centers the doom merchants whisper out fate... Even so, it would seem that, after all these years, after all these plagues and holocausts, the city is finally being rebuilt" (AC, p. 64).

But the disaster should remain to bring focus and structure to the city:

WHEELER: [a major world war] brings focus to people. They take sides, us against them... Now there's no war...No war, no focus. No focus, no structure. No structure spells disaster. ..And disaster is our business. .. curiosity breeds invention. We're here to invent and there's no invention. (AC, p. 95)

Wheeler believes that in order to invent something to bring focus and structure to people's life, they should "coldly calculate the public mind" ( $A C$, p. 95) and see what is marketable. Thus, art turns into a commodity, a business whose success is determined by invention. For this invention, they need to represent the unrepresentable disaster (Lyotard's postmodern sublime) which would be the epitome of disaster in postmodern era and they choose Rabbit to help them do that, for he is "supposed to be an artist... a kind of magician or something" dreaming things up in the form of a threedimensional invention ( $A C$, p. 67). What is parodic is that the characters in Angel City are not after building up a utopia but a dystopia and therefore, all the mythical figures turn from heroes to mock-heroes. Rabbit as the major artist of the play states:

RABBIT: [something] making me daydream at night. Causing me to wonder at the life of a recluse. The vision of a celluloid tape with a series of moving images telling a story to millions... millions seen and unseen... effecting their dreams and actions... replacing their families, replacing religion, politics, art, conversation. Replacing their minds. And I ask myself how can I stay immune?...I'm ravenous for power but I have to conceal it. (p. 69)

Moving pictures, the seventh art, is considered a popular art which can affect millions and millions of people's lives and dreams. Rabbit, formerly a committed artist knows that he cannot resist movies either and his hunger for power is not going to be satiated. The will-to-power is a part of Rabbit's motivation for succumbing to the siren lure of L.A. (Murphy, 2002). The target of Angel City is not so much Los Angeles or the movie business as the writer who sells out, the artist who succumbs to ambition and the desire for power and money, who becomes a spreader of the disease he was fighting, a promoter of fear through fake disaster. Rabbit is drawn to Hollywood by the power of the image. He is stuck in the world of simulation. Hollywood is a good place to "conceal the fact that the work-real, the production-real has disappeared" (Baudriallrd, 2000, p. 411). Through the death of the real image, the simulation of the image has appeared and through the death of the real power has the simulation of power. Rabbit as an originary artist is obsessed with power and its survival and simultaneously threatened with "displacement" (Rabillard, 1993, p. 87). Bottoms (1998, p. 133) calls Rabbit the lone Kafkaesque individual up against the monolithic system modeled directly after Faust (p. 140). He acknowledges that the values of power, money, and ambition have replaced the purer, more spiritual inspirations for creation that he had experienced on the desert, the Spanish missions, and Indian mythology. The old western myths turn out to be dysfunctional here and Hollywood with its plenitude of images replaces them. Hollywood is an entropic principle, a decreative universe. It represents the "dream dump" a region of exhausted cultural icons and debased fantasy and betrayed American dream (Wilcox, 1993, p. 64).

One of the historiographic features of the play is the same parodic nature most apparent in the American dream. Shepard in Angel City does not review the past American dreams nostalgically, but critically, since he believes that American dream was betrayed once in the past and drowned many people with itself. The juxtaposition of high culture (Rabbit's spiritual inspirations) and low culture (movie industry and Hollywood) is one of the other idiosyncrasies of Angel City as a postmodern play.

Apart from Rabbit, there is another artist in the play trying to make a big change. Tympani is "experiencing with various rhythm structures in the hope of discovering one which will be guaranteed to produce certain trance states in masses of people ( $A C$, p. 72)". Tympani describes the fact that the corrupt environment of the city and Hollywood is due to the corruption of the artists deceived by power and money:

TYMPANI: We're the brain of the city. The brain's demented. It's a demented brain... if we disturb the demented condition, the city will collapse around us. (AC, p. 78)

The artists as the brains of the city of art are disintegrators rather than integrators. Instead of being Beowulfian heroes who save the city from disasters through their art, they have become producers of disaster themselves. Tympani, like Wheeler and Lanx, is representative of an artist who is planning for something that would drive men crazy and make a catastrophe in the city:

RABBIT: You're always standing?

TYMPANI: Always. Waiting for it to happen.

RABBIT: What "it"?

TYMPANI: "It."

RABBIT: Oh. "It."

TYMPANI: The rhythm. The one, special, never-before-heard-before rhythm which will drive men crazy. (AC, p. 76)

Tympani whose name is also musical, is a parodic artist who does not know how to present his art to people. Like Rabbit, he has also been deceived by the aggrandizing Hollywood and is about to gain power and fame through making 
a new never-heard-before rhythm. For Tympani, movies are sources of improvisation and inspiration. In a surreal fashion and in a child-like language, he says that he does not "care about anything else, just the movies", not about the school, college, jobs, marriage, kids, or whatever else. But only "the dark, dark movies" (AC, p. 81). He muses: "what dya' say we just lose ourselves forever in the miracle of a film?” (AC, p. 96) The Hollywoodian hyperreality is very attractive for the artists of this play making them fabricate the absolute fake Hollywoodian art. Instead of being an originary artist, Tympani has become "the High Prophet of Disaster" but he does not know what best makes life a disaster for men. Rabbit says:

RABBIT: You should know what's commercial by now... we have to work on fear, not glory! Terror! Devastation! That's where the money is! Devastation!

RABBIT: WHAT IS THE MOST FRIGHTENING THING IN THE WHOLE WIDE WORLD!

TYMPANI: Dying.

RABBIT: WHAT IS IT THAT EVERYBODY IS SCARED OF!

TYMPANI: the expectation of a death unknown.

RABBIT: what is fear!

TYMPANI: THE IMAGINATION OF DYING!

RABBIT: THE IMAGINATION OF DYING IS MORE SCARY THAN ACTUALLY DYING! (AC, pp. 85-86)

Bizzarely, even fear should be marketable - Hollywood capitalizing on horror - and the more simulated and 'unreal' the fear, the more marketable and profitable it is.

Here there is a shift of attention to parodic "imagination" again. It is ironic that the imagination of dying is worse than dying itself. In the world of hyperreality, the simulation of reality is more understandable than the reality itself. "Death" in the movies is the simulation of death in real life. It is more believable and thus more frightening to see someone dead in a movie rather than in real life.

According to Tympani, Romantic comedies like the movies of Micky Rooney, Judy Garland and Dorsey brothers (p. 82) are no more appealing since people are not after "fun" anymore. They need something disastrous and frightening. Angel City has so many allusions to pop cultural figures, movies, screenplays etc. comprising the Barthesian myths of today which can be interpreted according to the pop culture of the modern era. Shepard's cultural icons are considered more emblematic, each standing for a specific field of art and each reviewing the history of their formation.

There is another artist figure-- Miss Scoons-- in the play through whom Shepard expresses many of his poetic theories regarding theater and characterization. Shepard has stated that in his earlier plays like Angel City the women characters were more "emblematic" (in Roudane, 2002, p. 73). Like Cavale, the artist figure of Cowboy Mouth, Miss Scoons is trying to discover herself as an actress but like the other artists of the play, Tympani and Rabbit, she is drowned in the power of the image:

MISS SCOONS: I look at the screen and I am the screen. I'm not me. I don't know who I am. I look at the movie and I am the movie. I am the star... I hate my life not being a movie... I hate being myself in my life which isn't a movie and never will be... [I hate] people living in dreams which are the same dreams I'm dreaming but never living. (AC, p. 77)

Miss Scoons identifies totally with the reified image of the star. She loses her "self" and becomes involved in the image the screen presents. In the movies, she sees people who are living in the world of dreams, but, since she cannot live in the same world in real life, she has developed mental problems. In a surrealist fashion, she falls into a trance and her philosophical words come in a 'stream of unconsciousness' manner. In this state, she presents a historiography of Los Angeles and relates it to the myth of capitalism now dominant in Hollywood and art production.

MISS SCOONS: the urge to create works of art is essentially one of ambition. The ambition behind the urge to create is no different from any other ambition. To kill. to win. To get on top

...

Greed is Greed. (AC, p. 88)

MISS SCOONS: the ambition to transform valleys into cities. To transform the unknown into the known without really knowing. To make things safe. To beat death. To be victorious in the face of absolute desolation. (AC, p. 89)

MISS SCOONS: El Pueblo de Nuestra Senora la Reina de Los Angeles de porciuncuta. En la ciudad. En todo el mundo. La muerte, esta es el rey supremo. Viva la muerto. (AC, p. 89)

Miss Scoons starts from the history of Los Angeles and the Spanish conquest with its lust for gold and its imperialistic violence. She talks about the greed and ambition to transform the unknown frontier into the known. The Spanish came to Los Angeles to make everything safe, but ironically they made everything unsafe. The Spanish founded "capitalism" in America and from then on, everything - including art - followed the same rules. The myth of capitalism is one of the main myths dealt with in Angel City. Cinema has been corrupted by capitalism and the artists who de-create rather than create. The city looks like a cinema or theater and the characters are more like mere images than real people. According to Baudrillard, The annihilation of reality is the result of capitalism:

For, finally, it was capital which was the first to feed throughout its history on the destruction of every referential, of every human goal, which shattered every ideal distinction between true and false, good and evil, in order to establish radical law of equivalence and exchange, the iron law of its power. (in Constable, 2010, pp. 44-45).

Money is one of the dominant motifs in Angel City. Here is Miss Scoons on money: 
MISS SCOONS: She slowly became aware of the truth behind the power of money....'money equals power, equals protection, equals eternal life' (p. 74)

The world of art depicted in this play is all just a business. Ironically, once in the play Miss Scoons reads a piece of text written by herself which is, according to Rabbit, "surprisingly original" and based on her own experience. The text, which can be considered a parody of art, is about the power of money. Tympani makes fun of Miss Scoons' outpouring:

TYMPANI: All I know is that you'll never get to third base with that kinda' drivel. That went out with Raymond Chandler.

RABBIT: Yeah, he's right. Ayn Rand sorta' did it to death too. (AC, p. 75)

Tympani's reference to pop culture authors such as Raymond Chandler and Rabbit's mentioning of high culture artists like Ayn Rand indicate Shepard's parody of the myth of capitalism. Ayn Rand - known as one of the most extreme advocates of reason, capitalism and egoism (Gotthelf, 2000) - is the author of Atlas Shrugged which depicts a dystopian United States. Ironically, America in Ayn Rand's novel is dystopian because its capitalists have gone on a strike and retreated to a mountainous hideaway. In Shepard's conception L. A. has turned into a dystopia precisely as a consequence of what the capitalists - including those in the art business - have done and do. Hence, Shepard's reference to Ayn Rand could be considered a parodic pastiche.

The Los Angeles we deal with in this play is a Baudrillardian apocalypse suffused by the parody of the end of reality, truth, knowledge, subjectivity, power, and politics (Constable, 2010, p. 46). Thus, as Hutcheon (1988, p. xii) has argued, the use of parody in postmodern historiographic literature is not for the sake of a nostalgic look to the past but as a means of critical reviewing of the past as part of the politics of representation.

Rabbit mentions the great detective story writer of American pop culture Raymond Chandler. Chandler also wrote screenplays for Hollywood; he wrote in the genre of noir. Besides, his writings were influential in this field. According to Paul Auster, Chandler "invented a new way of talking about America and America has never looked the same to us since" (in Chandler, 1992). The relation between Chandleresque writings and the dark disaster screenplay in Angel city is parodic. The screenplay Miss Scoons reads and claims to be hers, is believed to be written not by herself but by figures like Chandler, Fritz Lang or Howard Hawks. Even Miss Scoon's revelatory history of Los Angeles and her warnings against the commodification of art by the capitalist system of Hollywood cannot escape the reification of filmic pop imagery. What she says is counted as pulp fiction.

In a trance-like state of mind, Miss Scoons discloses more facts about this mysterious system:

MISS SCOONS: We're only going in circle. We're only going around and around. We're only getting nowhere.... There's nothing in here. The city's dead. The living are replacements for the dead. (AC, p. 87)

The whole play is structured on a vicious circle - going round and round in a corrupt system - aiming at the production of art and getting nowhere. Miss Scoons calls the artists "the messengers of God" who are "Frozen in the act of creation" (AC, p. 76). This is the parody of the myth of the artist as originator, throwing into high relief the dysfunctional heroes of Hollywood.

Myth of the mission is the last myth discussed in this part. Rabbitt as a composite of popular culture and film references parodically refers to the myth of mission, a staple of ersatz history of southern California (Wilcox, 1992, p. 66). In his travels to different parts of the New World, especially the frontier parts, he has become acquainted with different myths and legends of the natives. He explains that the south is the sign of the mouse (AC, p. 97), the place of innocence and trust; the west is the sign of the bear $(A C$, p. 97) which is the "looks-within" place; and, the east is the sign of the eagle, a place of illumination ( $A C$, p. 98$)$.

Wheeler confesses that he has gambled on imagination and lost while his dream had been to create an industry of imagination! (AC, p. 99) As he is not able to fulfill his wishes, he needs Rabbit and his myth of the west to transform Wheeler's theories of imagination to reality. Rabbit emphasizes that he is an artist and Wheeler is the producer. He accuses wheeler of not knowing anything about creation and wheeler justifies himself by calling creation a disease ( $A C$, p. 102).

Wheeler begins to narrate a story of Los Angeles at the state of siege (AC, p. 105) and a history of the America of the frontier past. But his story does not ultimately save him and he turns into a monster. Ironically, Rabbit discovers in the course of the act that he has become Wheeler. Wheeler shows him a kind of Ur-movie, an epic battle between a man and a woman that ends with the woman stabbing the man and then embracing him.

Finally, Wheeler picks up the medicine bundle that represents the West and self-knowledge, and they stand watching as out of it "a slow, steady stream of green liquid, the color of their faces, oozes from it onto the stage" (p. 111). Rabbit and Wheeler both turn green, the color of American money and Los Angeles smog (Cohn, 1995, p. 55).

\section{CONCLUSION}

Postmodern historiography reviews and questions the past representations, using parody as a technique that would bring about a critical distance. What we witness in the contemporary American culture is the remainder of the betrayed American dream of freedom, adventure, fame and fortune. The capitalist system, epitomized in Hollywood, portrays the past values of the Old West in the form of myths and rituals that belong more to the world of fantasy and hyperreality than to the real world of the past. In his artist plays, Sam Shepard manifests the decadence of the myth of the origin. He questions the contemporary condition of art and pictures the original art giving ground to the capitalist system. 


\section{REFERENCES}

[1] Barthes, Roland. (1957). Mythologies. New York: Noonday Press.

[2] Baudrillard, Jean. (2000). Simulacra and Simulations. In David Lodge and Nigel Wood (Eds.), Modern Criticism and Theory (pp. 404-412). ( $2^{\text {nd }}$ ed.). New York: Pearson Education Limited.

[3] Bottoms, Stephen J. (1998). The Theater of Sam Shepard, States of Crisis. Cambridge: Cambridge University Press.

[4] Callens, Johan. (2002). European Textures: Adapting Christopher Marlowe's Doctor Faustus. In Matthew Roudané (Ed.), Cambridge Companion to Sam Shepard (pp. 189-209). Cambridge: Cambridge University Press.

[5] Cohn, Ruby. (1995). Anglo-American Interplay in Recent Drama. Cambridge: Cambridge University Press.

[6] Constable, Cathrine. (2010). Science Fiction. In Richard Smith (Ed.), The Baudrillard Dictionary. Edinburgh: Edinburgh University Press.

[7] Chandler, Raymond. (1992). Farewell, My Lovely. New York: Vintage.

[8] Gotthelf, Allan. (2000). On Ayn Rand. Belmont: Wadsworth.

[9] Haqiqi, Manoochehr. (1383). Literary Schools. Tehran: Avay-e- nor.

[10] Hutcheon, Linda. (1988). A Poetics of Postmodernism. New York: Routledge.

[11] ---The Politics of Postmodernism.(1989). New York: Routledge.

[12] Innes, Christopher. (1993). Avant Garde Theater 1892-1992. London: Routledge.

[13] Lyotard, Jean-François. (1992).The Postmodern Explained. In Don Barry, Bernadette Maher, Julian Pefanis, Virginia Spate and Morgan Thomas (Trans.). Minneapolis: University of Minnesota Press.

[14] Malpas, Simon. (2005). The Postmodern. London: Routledge.

[15] Murphy, Brenda. (2002). Shepard Writes about Writing. In Matthew Roudané (Ed.), Cambridge Companion to Sam Shepard (pp. 123-138) Cambridge: Cambridge University Press.

[16] Rabillard, Sheila. (1993). Shepard's Challenge to the Modernist Myths of Origin and Originality: Angel City and True West. In Leonard Wilcox (Ed.), Rereading Shepard (pp. 77-96) London: Macmillan press.

[17] Roudané, Matthew. (2002). Shepard on Shepard: an Interview. In Matthew Roudané (Ed.), Cambridge Companion to Sam Shepard (pp. 64-80) Cambridge: Cambridge University Press.

[18] Shepard, Sam. (2006). Fool for Love and Other Plays. New York: Dial Press.

[19] Wilcox, Leonard. (1993). West's The Day of the Locust and Shepard's Angel City: Refiguring L.A Noir. Modern Drama 36, $61-75$.

Shima Shahbazi is an instructor of English literature at Sheikhbahaee University. She holds an MA in English literature from University of Isfahan (2011). Her fields of interest include cultural studies, modern and postmodern American drama, modern literary theory and, modern and postmodern fiction.

Hossein Pirnajmuddin is an Assistant Professor of English Literature at University of Isfahan, Iran, where he has taught since the completion of his $\mathrm{PhD}$ at University of Birmingham, UK, in 2002. His interests include Renaissance literature, colonial and postcolonial theory, postmodern fiction and translation studies. 